\title{
Role Controversy among Team Teachers in the JET Programme $^{1}$
}

\author{
Sean Mahoney \\ Fukushima University
}

This article attempts to identify and clarify incongruous and problematic perceptions of team teachers' roles held by JET Programme Assistant English Teachers (AETs) and their Japanese English-teaching colleagues (JTEs). Confusion over who should do what, and especially the frustration resulting from belief conflicts between team teachers, produces negative pressure on partners that could be detrimental to English lessons and general classroom atmospheres. Using data collected from long-answer sections of a nationwide questionnaire involving over 1,400 junior and senior high school educators, the author investigates discord found between and within AET and JTE groups at both levels. While respondents generally concurred on the main (i.e. top three) roles expected of themselves and their partners, discrepancies did arise regarding other, less commonly perceived roles.

本稿はJETプログラムの英語指導助手（AET）と日本人英語教師（JTE）によるティー ムティーチング（TT）授業において、両者の役割に関する問題や齟龉を指摘し、詳述す るものである。英語の授業におけるそれぞれの担当内容、特に教育方針の違いから生じる 不満が積もると、両者に否定的なプレッシャーを与え、教室内の雾囲気に悪影響を及ぼす ことになるだろう。中学校・高等学校で教えている全国 1,400 名以上の英語教師からの自 由記述データを利用して、筆者がAET集団とJET集団間、及び、それぞれの集団内部の問 題を検討する。全般的に、回答者からは各々のパートナーに期待されている主要な役割分 担に関して共通の認識を持っている割合が高かったが、双方に差異が見られる場合、役割 に関する共通認識の割合が低い傾向があった。

JALT Journal, Vol. 26, No. 2, November, 2004 


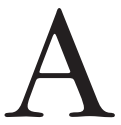
$s$ most language teachers in Japan realise, the JET Programme remains, after over 15 years of growth, the largest and arguably most powerful international programme through which English is being taught at junior and senior high schools nationwide. Many of its growing pains have been discussed by writers and speakers both in Japan (e.g. Institute, 1988; Brumby \& Wada, 1990; Wada \& Cominos, 1994; Adachi, Macarthur, \& Sheen, 1998; Pattimore \& Kobayashi, 1999; and Crooks, 2001) and around the world (e.g. Lai, 1999; McConnell, 2000) with each offering advice, criticism, encouragement, and (most valued of all) remedy. JET Programme assistant English teachers (AETs) currently number over 5,600, and hail from nine countries (JET Programme, 2003). The above studies evaluate these AETs' continuing impact on internationalisation, English education/pedagogy, and, more broadly, on Japanese society.

But what of research on team teaching and teachers' roles specifically? Concerns with the practice of team teaching of course rank highest among those most directly involved with the programme, but attempts made by both academic and mass-market writers to alleviate JTE and AET classroom problems have yet to provide entirely sufficient answers. Scores of Japanese guidebooks on "getting along with" AETs have flooded bookshops since JET's inauguration in 1987, with perhaps the most practical being Todd Leonard's bilingual reference, Team Teaching Together (1994). What actually occurs in team-taught classes, on the other hand, has been examined through direct observation of a limited number of team-teaching pairs (e.g., Garant, 1992; Yukawa, 1992), and other focused case studies (e.g., Sturman, 1992; Kahny, Olivieri, \& Maybin, 1992). More recently, Adachi, et al., (1998) surveyed thousands of students and nearly one hundred team teachers; yet while their conclusions regarding the harmonisation of exams with team-taught classes resemble those to follow, they did not provide information on how JTEs and AETs perceive their own and each others' roles.

An earlier series of questionnaires conducted by the Institute for Research in Language Teaching (1988) asked eighty-eight AETs to check any of nine "activities you feel you would like to do, including what you are now doing." While the Institute's researchers did allow AETs to describe "other" possible roles for themselves and elicited 171 JTE responses on how they utilised their AETs, neither JTE roles nor JTE perspectives on AET roles were addressed in any of the questions on any of the questionnaires.

Beyond these, only two works have collected and examined data on JET team teaching concerns through nationwide, questionnaire-based 
investigations. ${ }^{2}$ While Japan's Council of Local Authorities for International Relations (CLAIR) has recently released a detailed, evaluative report on JET in its JET Puroguramu Hyouka Chosa (2001), its objectives did not include determination or discussion of teachers' roles. Yamada's (Ed., 1996) report on the JET Programme covered an array of issues, and was consulted in the creation of the questionnaire to be discussed in this paper. However, querying the issue of how team teachers perceive roles in the classroom must not only be updated, but must also be reformatted. This study does so through an open-ended question on AET and JTE (i.e. self and partner) roles, rather than through multiple-choice questions on AET roles alone.

The present study also differs from the two above in that it assumes teaching related conflicts can and do arise as a result of confusion over JTE and AET roles, the number one stress voiced by AETs (Voci-Reed in Wada \& Cominos, 1994). Frustration at the gaps between what teachers believe they are supposed to be doing and what they find themselves actually doing, difficult enough for those teaching on their own, can be compounded in team-teaching situations since gaps may exist between the two individuals' perceptions of both ideal and actual roles. And if teachers' actions in the classroom are indeed fundamentally based upon what they believe (a position elucidated by numerous scholars including Lynch, 1989; Woods, 1991, and with regard to ESL in Johnson, 1992), teachers' handwritten comments on roles should provide a valuable window upon potential remedy. Thus, the open-ended question to be examined in this paper pertains to perceptions of ideal roles, and seeks to identify and deliberate both common and differing beliefs about roles as held by AETs and JTEs throughout Japan.

\section{Method}

In early 1999, the Japanese Ministry of Education, Science, Sports, and Culture (hereinafter Monbukagakusho) agreed to sponsor a nationwide inquiry into team-teaching related problems. In October 1999, a pilot questionnaire was devised and sent to nine JTEs, six AETs, and two native English-speaking professors of English, the latter of whom had had experience in questionnaire design. As a result of pilot participants' frank and informative comments, ten questions were subsequently revised (in both English and Japanese versions), and one question was cut completely. The revised four-page questionnaire was then distributed in English (one copy) and Japanese (two copies) to 2000 schools, and 
netted responses from 431 Assistant English Teachers (AETs) and 971 Japanese Teachers of English (JTEs) teaching at junior and senior high schools. Although the total number of JTEs and AETs teaching at each of these 2,000 schools at the time is unknown, 288 of 1,000 junior high schools and 305 of 1,000 senior high schools (i.e. $29.7 \%$ of all schools) responded, with an average of 2.4 questionnaires received from each.

The following open-ended question, verified through back translation by a native English-speaking professional translator, appears in Part 2 Section 1 of the questionnaire, and will be the focus of this paper:

JTEs and ALT/AETs are supposed to play different roles in team teaching. Please describe briefly your perception of these roles in the space below.

[AET's roles]:

[JTE's roles]:

Responses from team teachers varied in length from simple listings of a main role or two (e.g. "Speaking English. Engaging students in conversation") to several paragraphs of informed, detailed comment. Organising this data into a coherent picture of what teachers were saying of course required a means of summarising comments and, as twenty-four multiple-choice questions elsewhere in the questionnaire supplied "objective" responses (see Inoi, Yoshida, Mahoney, \& Itagaki, 2001) that were easier to tally, it was decided to preserve the individuality of handwritten answers as much as possible while creating general response categories. To achieve this, belief categories regarding teachers' roles were derived from the handwritten comments themselves (i.e. not premeditated), and were described using common keywords drawn therefrom. As a result, a large number of categories needed to be created; there were as many as 38 in the case of AET perceptions of their own roles. Despite this seemingly unwieldy number of categories, however, the top 15 of these 
represent 825 of the total 881 AET comments (93.6\%).

The following is an example of the method used to process data obtained from the 431 junior and senior high school AET respondents, though the same method was also employed for JTE responses. The most commonly cited AET role was "Offer English conversation and pronunciation model/talk to students," with 219 of 431 respondents (105 at the junior high level, 114 at senior high) including the concept somewhere within their comments, for example: "My perception of the AET's role is to assist the English/oral communication teacher in pronunciation, grammar, definition, and sharing cultural experiences." Data were recorded and grouped using the following shorthand (in which each italicised number represents a particular respondent):

204 Junior High AETs: 227 Senior High AETs Total: 431 Respondents, 881 Comments

1. "Offer English conversation and pronunciation model/talk to students"

[219 citations] $(105 ; 114)=51.0 \%$ of junior high AETs: $50.2 \%$ of senior high AETs

$1,2,7, \ldots 77,78,84 / 85 / 257 / 107 / 141 / 142 / 144$ pronunciation, 89 , 90, 91, 93, 94, 98, 99, 103, 105, 106, 108, 109, 110,111-speech, 114, 115, 119-and spelling, 121,..146, 149-facilitate OC [Oral Communication], 150, 151, 153, 154*, 155, 156, 157, 161, 163, 165*, 168, ...428, 429, 430 .

Thus, to decode the shorthand: beginning with the brackets under the category heading, we see that 219 (of 431) AET respondents (105 junior high; 114 senior high) described this role. In the following line, virgules were placed between certain respondent numbers to indicate answers that resembled one other in their particular emphases, as qualified (e.g. 84/85/... 144 pronunciation). Hyphens in the above shorthand (e.g. "111-speech") precede qualifications and details added to individual comments that otherwise belonged to this category. Asterisks denote particularly illustrative and developed responses that may be quoted in subsequent research.

It should also be noted that there were 33 ( $n=431$ AETs) completely blank responses to this question, while nine described only AET roles, 
with two AETs writing exclusively on JTE roles. On the JTE side, there were 170 ( $\mathrm{n}=971$ ) blanks, with 22 JTEs describing only JTE roles, and three writing on AET roles alone. In general, AETs wrote more than their Japanese colleagues.

I must stress here, however, the dangers of interpreting the numerical results in the following tables too literally. The numbers are intended solely to provide a guide to the contents of hundreds of pages of data. Reality is such that even when researchers rely on keywords to group long-answer comments, there is inevitably a degree of subjectivity involved in creating categorisations from raw qualitative data. And of course any two researchers' analyses of long-answer questions may vary to some extent. However, while one researcher may decide for example that the two written comments "the JTE should translate" and "the JTE should interpret" describe the same role, and another may choose to keep them separate, neither would group these comments under a category headed "the JTE should discipline students."

Nonetheless, six raters (three native speakers of each language) with experience in SLA research were enlisted to test the consistency of response categorisation. Intrarater correlation rates, or the raw agreement indices for dichotomous ratings in which the total number of actual agreements across all categories is divided by the total number of possible agreements, were $97.4 \%$ and $96.8 \%$ for the data on JTEs and AETs, respectively. But one last caveat: because this questionnaire was conducted in two very different languages, and a native speaker of each read and grouped the responses, the categorised comment types produced in an unpremeditated manner from Japanese and English sets of raw data do not (and I contend cannot) correspond entirely. In fact, one of the most revealing characteristics of the role categorisations is precisely that JTEs and AETs do describe team-teaching roles using not only different languages (i.e. Japanese and English), but also different concepts within these languages. More will be made of this point throughout the discussion section of this paper. Lastly, the author maintains that the method employed here is the best alternative to that of simply reproducing (i.e. retyping) teachers' comments in full (as has been done by Yamada, 1996) or that of forcing all responses into literally prescribed categories. The latter imposes too much upon the respondent, the former upon the reader. 


\section{Results and Discussion}

\section{Part 1: The Role of the AET}

While Yamada (1996) discovered through multiple-choice questions that JTEs reportedly employed their assistants as language resources slightly more frequently than as cultural referents, our analyses indicate otherwise. For many JTEs, but especially those working in junior high schools, the AET's chief role is to demonstrate or be a model of his or her culture (or more vaguely, "foreign culture"). This accounted for $41.4 \%$ of responses, or 196 of the 473 junior high teachers surveyed. But $50.5 \%$ of the 473 AETs, on the other hand, perceived their main role as that of offering an English conversation and pronunciation model (i.e. linguistic rather than cultural). ${ }^{3}$ While language can, of course, be considered a part of culture, and to mention language does not necessarily preclude culture (though 58 JTEs and 119 AETs felt the need to mention both), one wonders why perceptions of these key AET roles might differ between native English speakers and their Japanese counterparts.

Of several possible explanations, the most obvious is that "culture" is conceptually broader than "language" and, as Japanese English teachers already share a good deal of cultural background with the vast majority of their students, the introduction of an AET into a classroom is first and foremost an act of adding another culture to the learning environment. Teachers (and students) may thus see AETs first as culturally "foreign," then as English-speaking assistant teachers. The AETs themselves, on the other hand, may feel that the primary bridge to be built between themselves and their new classroom environment is one of language, and that adapting to Japanese formal learning culture may be accommodated later. Alternative explanations must note discrepancies between what JTEs and AETs are told, and not told, about each other's roles. The Monbusho (now the Monbukagakusho) published a Handbook for Team Teaching in 1994, in which the following AET (or ALT, Assistant Language Teacher) roles are outlined. The Monbukagakusho continues to issue copies of the Handbook to new AETs at JET Programme orientations:

The ALTs assigned to schools are expected to carry out the following duties under the guidance of their supervisors and the Japanese Teachers of Language (JTLs):

(1) Assist with classes taught by the JTL 
(2) Assist with the preparation of supplementary teaching materials

(3) Assist with language training/practice for JTLs

(4) Assist with the instruction of "English/French/German Speaking Societies" and other extra-curricular activities

(5) Provide language information for teachers' consultants and JTLS

(6) Assist with English/French/German speech contests

(7) Assist with other duties as specified by the participant's host institution

More specifically, the duties of the ALT at school are to assist the JTL in developing students' communicative abilities in the language and to serve as a cultural resource person so that students can develop a capacity for understanding foreign cultures and customs. The ALT is also expected to help JTLs further improve their own abilities in the target foreign language through everyday contact with them, in small group meetings, or in more formal seminars (Monbusho, 1994, p. 8).

The above describes duties involving "language" in (3) and (7) first, with "cultural resource" noted farther down the list. And again, we might assume that all concerned AETs familiarise themselves with Handbook guidelines: Japanese teachers may have to search their local boards of education for them. A further obstacle to clarifying team-teaching roles is that official information regarding JTE roles is not made widely available to either partner.

Teaching language and teaching culture may and often do occur simultaneously, but the issue may at times lead to problems in assigning priority to classroom tasks. And perhaps more significantly, the JTE's perception of his or her counterpart's main role strongly influences classroom design. To take an extreme example, a teacher who sees the AET as a cultural representative or even "the embodiment of foreign culture" as one JTE described, someone whose role and comments must always be explained to students (in Japanese), may be restricting his or her AET to the role of an intriguing anomaly, expected simply to "be foreign" (a role actually mentioned by 11 AETs in this survey). Teachers who regard their AETs chiefly as language resources, however, may at- 
tribute higher status to them since, at least where language issues like pronunciation are concerned, native speakers often carry patent authority (Brumby \& Wada, 1990, p. 12). We may surmise here that the origin of a good portion of the friction between many team-teaching partners lies in confusion or even clashes over which of these two main AET roles is more important (see Wada \& Cominos, 1994, pp. 63-70).

Table 1 shows the relative frequency of AET response types from junior and senior high schools. Very little difference may be observed among the top four AET roles. However, the number of junior high AETs who felt that they should "conduct exercises/devise games" was just as large (10.8\%) as those who saw the need for AETs to "promote creative/alternative teaching methods." One reason for this discrepancy may be that junior high school classrooms may allow more time to be spent on exercises and games than the more academic high school environment; having said this, however, one cannot ignore that the AET role to "teach grammar/syntax" also registered much higher among junior high respondents. This may be understood if one considers that the grammar being taught at this level may be explained by AETs in simple English, and that example sentences can more easily be produced impromptu (as in the words of one AET, in order "to bring the grammar/situation to life"). Still more helpful an explanation, however, may be the fact that high school English classes are themselves already organised into "General English" (usually of two levels), "Oral Communication" (three levels), a "Reading," and a "Writing" class (Monbusho, 1989). AETs are most often placed in one or more of the "Oral Communication" classes, where one may assume there would be ample opportunity to teach (as Japanese teachers expressed) "... useful and practical idioms and expressions," a role noted almost four times as frequently by senior high JTEs (at 5.8\%) than their counterparts at junior high schools (at 1.5\%).

Another significant difference between the two groups of AETs lies in their attitudes toward power relationships, as expressed in comment type numbers 6, "roles of AET and JTE should be equal, both held to the same standards," and 9, "roles of AET and JTE are flexible." These comments ranked $6^{\text {th }}$ and $7^{\text {th }}$ among senior high respondents, yet only $8^{\text {th }}$ and $13^{\text {th }}$ among those employed at junior high schools. The two quotations that follow represent AET frustration with the current system, in which they are allotted either too little or too much responsibility:

I can say that I do not believe my situation to be 'ideal'-if I am to wield as much power over lesson preparation and presentation 


\section{Table 1. AET Perceptions of AET Roles ( $n=431 ; 204$ Junior High, 227 Senior High)}

\begin{tabular}{|c|c|c|c|c|c|}
\hline $\begin{array}{l}\text { Overall } \\
\text { Ranking }\end{array}$ & Comment Type & Jun & $\begin{array}{l}\text { r High } \\
\text { ink }\end{array}$ & Sen & $\begin{array}{l}\text { r High } \\
\text { ink }\end{array}$ \\
\hline 1 & $\begin{array}{l}\text { Offer English conversation and } \\
\text { pronunciation model/Talk to students }\end{array}$ & 1 & $\begin{array}{l}51 \% \\
(105)\end{array}$ & 1 & $\begin{array}{l}50 \% \\
(114)\end{array}$ \\
\hline 2 & Share culture & 2 & $\begin{array}{l}39 \% \\
(79)\end{array}$ & 2 & $\begin{array}{l}43 \% \\
(98)\end{array}$ \\
\hline 3 & Motivate/prompt/encourage & 3 & $\begin{array}{l}29 \% \\
(59)\end{array}$ & 3 & $\begin{array}{l}31 \% \\
(71)\end{array}$ \\
\hline 4 & Assist in lesson planning & 4 & $\begin{array}{l}17 \% \\
(34)\end{array}$ & 4 & $\begin{array}{l}16 \% \\
(36)\end{array}$ \\
\hline 5 & $\begin{array}{l}\text { Promote creative/alternative teaching } \\
\text { methods }\end{array}$ & 5 & $\begin{array}{l}11 \% \\
(22)\end{array}$ & 5 & $\begin{array}{l}15 \% \\
(33)\end{array}$ \\
\hline 6 & $\begin{array}{l}\text { Roles of AET and JTE should be } \\
\text { equal, both held to the same stand- } \\
\text { ards }\end{array}$ & 8 & $\begin{array}{l}5 \% \\
\text { (11) }\end{array}$ & 6 & $\begin{array}{l}11 \% \\
(25)\end{array}$ \\
\hline 7 & Conduct exercises/devise games & 5 & $\begin{array}{l}11 \% \\
(22)\end{array}$ & 9 & $\begin{array}{l}4 \% \\
(8)\end{array}$ \\
\hline 8 & Teach grammar/syntax & 7 & $\begin{array}{l}7 \% \\
(15)\end{array}$ & 10 & $\begin{array}{l}3 \% \\
(6)\end{array}$ \\
\hline 9 & Roles of AET and JTE are flexible & 13 & $\begin{array}{l}2 \% \\
(3)\end{array}$ & 7 & $\begin{array}{l}7 \% \\
(15)\end{array}$ \\
\hline 10 & Act as resource for JTE and students & 9 & $\begin{array}{l}4 \% \\
(8)\end{array}$ & 9 & $\begin{array}{l}4 \% \\
(8)\end{array}$ \\
\hline
\end{tabular}

* Three comment types ranked $9^{\text {th }}$ among junior high AETs (with 8 responses each). The other two were "help JTEs improve English/speak with JTEs" (ranked $12^{\text {th }}$ Overall) and "help with listening skills" (14 $4^{\text {th }}$ overall).

** Ranked $8^{\text {th }}$ on the senior high list was "be an object of curiosity," (with 9 responses, $11^{\text {th }}$ overall).

*** Ranked $10^{\text {th }}$ on the junior high list was "develop friendship with students " (with 7 responses, $15^{\text {th }}$ overall). 
as I currently do, I should also have more influence outside the classroom.

Although my role is as an assistent [sic], I'm actually the teacher of the class. We don't use textbooks and all lesson plans are done from start to finish by me.... At my school, the JTE usually has a very secondary role when it comes to in-class teaching.

David McConnell, in a penetrating investigation of the JET Programme, Importing Diversity, also notes that many Japanese English teachers either conduct all or none of their supposedly team-taught lessons (McConnell, 2000). Citing the results of a national survey by the Institute for Research in Language Teaching, he laments that 30\% of JTEs let the AET take over their classes, 25\% report that they themselves are central, and only 36\% claimed actually to share teaching duties (Institute for Research in Language Teaching, 1988, cited in McConnell, 2000, p. 211). Despite continuing programme improvements since 1988, including an increasing number of conferences on team teaching for JTEs (McConnell, 2000, p. 216), it appears that AETs, particularly those at the high school level, still seek a more desirable balance in the team workload, with some demanding more responsibility and others less.

AET calls for and comments on a necessary degree of flexibility in teachers' roles accounted for over $4.6 \%$ of the total AET comments, and should be mentioned as a caveat to overprescribing AET and JTE roles. An assistant teacher in Gunma remarks:

Although both AET and JTE have distinct skills which they bring to the team teaching relationship, I do not believe that there are rigidly defined roles for each. This, I'm afraid, only leads to an inflexible teaching environment and stagnancy.

An AET from Kumamoto felt that "since ALTs have virtually no real power in the career hierarchy," roles must vary in accordance with school and individual JTE expectations. As some degree of controversy over roles occurs in all but ideal team-teaching pairs, teachers should inform each other of their perspectives before working together, and from time to time throughout the year. Unfortunately, the required moments for calm discussion come infrequently, if at all, in many school settings; hence the comment types "lack of lesson planning" and "no time for meeting with AETs" registered first among team-teaching concerns expressed by AETs and JTEs, respectively (Inoi et al., 2001, pp. 39-40). 
Turning now to JTE comments on AET roles (Table 2, below), the idea of flexibility appears again, but not in the same terms or numbers. JTEs generally do not regard their AETs as equals. Still, the belief that AETs are "equal coworkers" can be found, though at 2.1\% just barely, among the top ten junior high JTE responses (see note below Table 2). Six junior high JTEs deemed AETs "equal," but as "partners" rather than as associate

Table 2. JTE Perceptions of AET Roles ( $n=971 ; 473$ Junior High, 498 Senior High)

\begin{tabular}{|c|c|c|c|c|c|}
\hline $\begin{array}{l}\text { Overall } \\
\text { Ranking }\end{array}$ & Comment Type & & $\begin{array}{l}\text { r High } \\
\text { ank }\end{array}$ & Sen & $\begin{array}{l}\text { r High } \\
\text { ank }\end{array}$ \\
\hline 1 & $\begin{array}{l}\text { Model, demonstrator, informant on au- } \\
\text { thentic English culture }\end{array}$ & 1 & $\begin{array}{l}41 \% \\
(196)\end{array}$ & 1 & $\begin{array}{l}33 \% \\
(162)\end{array}$ \\
\hline 2 & $\begin{array}{l}\text { Model, demonstrator, informant source } \\
\text { of authentic and natural English }\end{array}$ & 2 & $\begin{array}{l}21 \% \\
(100)\end{array}$ & 2 & $\begin{array}{l}25 \% \\
(124)\end{array}$ \\
\hline 3 & $\begin{array}{l}\text { Motivator, stage-setter for English les- } \\
\text { sons }\end{array}$ & 3 & $\begin{array}{l}19 \% \\
(88)\end{array}$ & 3 & $\begin{array}{l}21 \% \\
(106)\end{array}$ \\
\hline 4 & $\begin{array}{l}\text { Instructor for English pronunciation, } \\
\text { listening comprehension }\end{array}$ & 4 & $\begin{array}{l}15 \% \\
(73)\end{array}$ & 5 & $\begin{array}{l}10 \% \\
(48)\end{array}$ \\
\hline 5 & Teaching plan maker & 6 & $\begin{array}{l}5 \% \\
(24)\end{array}$ & 4 & $\begin{array}{l}16 \% \\
(77)\end{array}$ \\
\hline 6 & Assistant for CLT activities & 5 & $\begin{array}{l}12 \% \\
(59)\end{array}$ & 8 & $\begin{array}{l}5 \% \\
(24)\end{array}$ \\
\hline 7 & Chief classroom manager, conductor & 8 & $\begin{array}{l}3 \% \\
(13)\end{array}$ & 6 & $\begin{array}{l}9 \% \\
(43)\end{array}$ \\
\hline 8 & Class assistant & 7 & $\begin{array}{l}4 \% \\
(19)\end{array}$ & 8 & $\begin{array}{l}5 \% \\
(24)\end{array}$ \\
\hline 9 & $\begin{array}{l}\text { Teacher of useful and practical idioms } \\
\text { and expressions }\end{array}$ & 12 & $\begin{array}{l}2 \% \\
(7)\end{array}$ & 7 & $\begin{array}{l}6 \% \\
(29)\end{array}$ \\
\hline 10 & $\begin{array}{l}\text { Provider and resource of a great amount } \\
\text { of English input }\end{array}$ & 9 & $\begin{array}{c}2 \% \\
(11)\end{array}$ & 9 & $\begin{array}{l}3 \% \\
(17)\end{array}$ \\
\hline
\end{tabular}

* Ranked $10^{\text {th }}$ on the junior high list was "equal co-worker" (with 10 responses, $13^{\text {th }}$ overall).

** Ranked $10^{\text {th }}$ on the senior high list was "evaluator, school report writer" (with 13 responses, $11^{\text {th }}$ overall). 
professionals. In senior highs, where responses were more widely distributed, only two out of 498 JTEs $(0.4 \%)$ saw their assistants as equals in either sense. However, many more senior high teachers, 43 of 498 (8.6\%), saw their AET as "chief classroom manager, conductor," which ranked $6^{\text {th }}$ among response types, with remarks such as "AETs are NOT 'assistants'," and some suggesting that the JTE role is the true auxiliary. This latter perspective was particularly prevalent among senior high AETs, of whom (in Table 4) $10.1 \%$ believed their JTE should be "assistant to [the] AET," the $8^{\text {th }}$ most commonly noted JTE role.

While a fair number of senior high teachers felt AETs were supposed to be class managers, only 13 of 473 (2.7\%) junior high JTEs appear to share this belief. This helps explain the significantly higher level of power-relationship frustrations expressed by senior high AETs. Senior high school JTEs who work, one assumes, with AETs in special "oral communication" classes appear more likely than their junior high counterparts to assign the role of classroom leader to AETs. Finally, while only a negligible number of senior high teachers saw their partners as equals, and many viewed them rather as either classroom or communicative language teaching "assistants" on the one hand, or (more often) as "managers" on the other, we may now qualify McConnell's earlier statement by adding that the trend to polarize AET classroom roles is particularly prevalent among teachers at the senior high level. In fact, $10.6 \%$ of senior high JTEs saw their own role (Table 3, below) as assistants to AETs (e.g. "An AET auxiliary"), compared with only $2.5 \%$ of junior high JTEs. Moreover, another comparatively active AET role, "teaching plan maker, lesson plan idea provider," (e.g. "To create plans in accordance with evaluation of students' abilities"), was specifically mentioned by $15.5 \%$ of senior high JTEs, in contrast to only $3.7 \%$ of their middle school counterparts.

With this data in mind, then, some distinction between the two school levels appears warranted in future considerations of how AETs should be employed. Tailoring AET (and corresponding JTE) roles in accordance with junior and senior high differences may help reduce stress caused by unfulfilled expectations on all sides.

\section{Part 2: The Role of the JTE}

As mentioned previously, there is a significant absence of directives from the Ministry of Education regarding JTE roles in team-taught classes. It would, admittedly, be extremely difficult for the Ministry to 
standardise roles for JTEs: the responses collected in this study vary and one may argue should vary in accordance with the unique relationship each JTE shares with the assigned AET. Still, the following top ten list (Table 3) of most commonly mentioned JTE roles, as described by JTEs themselves, may provide guidance for those seeking clearer definition of team-teaching roles.

Table 3. JTE Perceptions of JTE Roles ( $n=971 ; 473$ Junior High, 498 Senior High)

\begin{tabular}{|c|c|c|c|c|c|}
\hline $\begin{array}{l}\text { Overall } \\
\text { Ranking }\end{array}$ & Comment Type & Jun & $\begin{array}{l}\text { r High } \\
\text { ank }\end{array}$ & Sen & $\begin{array}{l}\text { r High } \\
\text { ank }\end{array}$ \\
\hline 1 & Explainer, intermediator & 1 & $\begin{array}{l}33 \% \\
(158)\end{array}$ & 1 & $\begin{array}{l}35 \% \\
(172)\end{array}$ \\
\hline 2 & Manager, driving force in class & 2 & $\begin{array}{l}19 \% \\
(89)\end{array}$ & 2 & $\begin{array}{l}26 \% \\
(127)\end{array}$ \\
\hline 3 & Teaching-plan maker & 3 & $\begin{array}{l}14 \% \\
(67)\end{array}$ & 3 & $\begin{array}{l}13 \% \\
(64)\end{array}$ \\
\hline 4 & $\begin{array}{l}\text { Understand students' levels of achieve- } \\
\text { ment, realities }\end{array}$ & 7 & $\begin{array}{l}6 \% \\
(28)\end{array}$ & 4 & $\begin{array}{l}12 \% \\
(60)\end{array}$ \\
\hline 5 & Interpreter, interpretation if necessary & 6 & $\begin{array}{l}7 \% \\
(33)\end{array}$ & 8 & $\begin{array}{l}8 \% \\
(38)\end{array}$ \\
\hline 6 & Assistant to AET & 10 & $\begin{array}{l}3 \% \\
(12)\end{array}$ & 5 & $\begin{array}{l}11 \% \\
(53)\end{array}$ \\
\hline 7 & Coordinator, mood-setter & 8 & $\begin{array}{l}5 \% \\
(24)\end{array}$ & 7 & $\begin{array}{l}8 \% \\
(39)\end{array}$ \\
\hline 8 & $\begin{array}{l}\text { Supporter, counsellor for unsuccessful } \\
\text { learners, dropouts }\end{array}$ & 4 & $\begin{array}{l}9 \% \\
(42)\end{array}$ & 11 & $\begin{array}{l}3 \% \\
(13)\end{array}$ \\
\hline 9 & $\begin{array}{l}\text { Explainer (in Japanese) of grammatical } \\
\text { complexities }\end{array}$ & 5 & $\begin{array}{l}9 \% \\
(41)\end{array}$ & 12 & $\begin{array}{l}2 \% \\
(12)\end{array}$ \\
\hline 10 & Exercise discipline & 19 & $\begin{array}{c}0.2 \% \\
(1)\end{array}$ & 6 & $\begin{array}{l}9 \% \\
(44) \\
\end{array}$ \\
\hline
\end{tabular}

* Three comment types ranked $10^{\text {th }}$ among junior high JTEs (with 12 responses each): "Assistant to AET" ( $5^{\text {th }}$ overall), "Partner to AET on equalterms" $\left(13^{\text {th }}\right.$ overall), and "Model, demonstrator of English conversation with AETs" (11 ${ }^{\text {th }}$ overall). The $9^{\text {th }}$ most commonly mentioned role was "Advisor on students' general school life" (13 responses, $13^{\text {th }}$ overall).

**Among senior high JTEs, the $9^{\text {th }}$ and $10^{\text {th }}$ most frequently mentioned roles were "Model, demonstrator of English conversation with AETs,"(31 responses, 11 ${ }^{\text {th }}$ overall) and "Encourage students" 25 responses, $12^{\text {th }}$ overall) respectively. 
Although the top three JTE roles coincided among JTEs at both school levels, senior high teachers were more likely to see themselves as "manager, driving force in class" (25.5\% vs. $18.8 \%$ in junior high). A fair number of (mainly senior high) AETs, on the other hand, saw their JTEs' role as one of support or assistance (10.1\% senior, $5.4 \%$ junior in Table 4, following). Even more curious is that junior high JTEs appear less likely to designate either themselves (18.8\% cf. $25.5 \%)$ or their partners $(2.7 \%$ cf. 8.6\%) as "managers" of the class, and thus seem to assume a less rigid attitude toward the delegation of responsibilities, perhaps entrusting different duties to each partner as circumstances require. In any case, one can see that senior high JTEs and AETs are less likely to be found swapping the role of manager in their classrooms.

Comparisons between role rankings in Tables 3 and 4 suggest that team teachers' expectations of student-teacher relations also differ considerably. Whereas AETs at both levels list "maintain discipline" (Table 4) as either the most or second most important JTE role, junior and senior high JTE respondents painted a completely different picture. Disciplining ranked $6^{\text {th }}$ (at $8.8 \%$ in Table 3 ) among teachers working with older students, and a remote $19^{\text {th }}$ (at $0.2 \%$ ) in the minds of junior high JTEs. Ironically, it is at the junior high level that, according to Table 4, a higher percentage of AETs expect their partners to lead on the issue (16.7\% cf. 8.8\% in senior highs); and though AETs are told to rely on their JTEs for student discipline (Monbusho, 1994), a minority have taken the matter into their own hands, historically doing more harm than good both to student-teacher relationships and their own teaching team (see McConnell, 2000, pp. 182-83). By and large, though, assistant English teachers do see their partners as chief disciplinarians, a belief that has possibly been created through JET Programme orientations, at which they are specifically informed that AETs are not to discipline children. Still, greatly divergent expectations about who is to play disciplinary roles, when, and to what extent, do lead to disappointment among some teams.

As previously mentioned, there are also noticeable gaps among junior and senior high JTEs' views on discipline, and another look at Table 3 (JTE views on their own roles) reveals still more dimensions to this self-portrait. Though having an understanding of students' levels of achievement and of their realities ranked high in both groups $\left(7^{\text {th }}\right.$ and $4^{\text {th }}$ respectively in junior and senior high), junior high educators in particular stressed the additional roles of supporting and counselling unsuccessful learners ( $4^{\text {th }}$, at $8.9 \%$ ), and of providing advice on students' school life $\left(9^{\text {th }}\right.$, at $\left.2.7 \%\right)$. Senior-high level teachers, however, saw their roles as, 
comparatively speaking, less parental, yet more active in encouraging $\left(10^{\text {th }}\right.$ at $\left.5.0 \%\right)$ but not necessarily supporting/counselling students $\left(11^{\text {th }}\right.$ at $2.6 \%$ ), and were found more responsible for "exercis[ing] discipline" $\left(6^{\text {th }}\right.$, at $\left.8.8 \%\right)$. As an example of comments in this role category, a senior high teacher in Ishikawa Prefecture wrote that JTEs should "pay attention to students' behaviour in class (i.e. discipline)." Perhaps since compulsory education in Japan means that students must attend school until they graduate from junior high (which virtually all do, since failing is not practiced; the rare nongraduate is free to leave school at age 16), junior high educators may well be doing everything it takes to keep their students coming back to school the next day, while senior high teachers may simply not put up with (and do not legally have to put up with)

Table 4. AET Perceptions of JTE Roles ( $n=431 ; 204$ Junior High, 227 Senior High)

\begin{tabular}{|c|c|c|c|c|c|}
\hline \multirow{2}{*}{$\begin{array}{l}\text { Overall } \\
\text { Ranking } \\
1\end{array}$} & \multirow{2}{*}{$\begin{array}{l}\text { Comment Type } \\
\text { Translation }\end{array}$} & \multicolumn{2}{|c|}{$\begin{array}{l}\text { Junior High } \\
\text { Rank }\end{array}$} & \multicolumn{2}{|c|}{$\begin{array}{l}\text { Senior High } \\
\text { Rank }\end{array}$} \\
\hline & & 4 & $\begin{array}{l}20 \% \\
(41)\end{array}$ & 1 & $\begin{array}{l}28 \% \\
(63)\end{array}$ \\
\hline 2 & Maintain discipline & 1 & $\begin{array}{l}26 \% \\
(53)\end{array}$ & 2 & $\begin{array}{l}22 \% \\
(50)\end{array}$ \\
\hline 3 & Design lesson plans & 3 & $\begin{array}{l}23 \% \\
(46)\end{array}$ & 5 & $\begin{array}{l}13 \% \\
(30)\end{array}$ \\
\hline 4 & $\begin{array}{l}\text { Provide explanations on/teach gram- } \\
\text { mar }\end{array}$ & 2 & $\begin{array}{l}25 \% \\
(50)\end{array}$ & 7 & $\begin{array}{l}11 \% \\
(25)\end{array}$ \\
\hline 5 & Model communicative relationship & 6 & $\begin{array}{l}14 \% \\
(28)\end{array}$ & 3 & $\begin{array}{l}17 \% \\
(39)\end{array}$ \\
\hline 6 & Lead class & 5 & $\begin{array}{l}17 \% \\
(34)\end{array}$ & 10 & $\begin{array}{l}9 \% \\
(20)\end{array}$ \\
\hline 7 & Motivate students & 7 & $\begin{array}{l}12 \% \\
(25)\end{array}$ & 6 & $\begin{array}{l}12 \% \\
(27)\end{array}$ \\
\hline 8 & Equal roles & 10 & $\begin{array}{l}7 \% \\
(14) \\
\end{array}$ & 4 & $\begin{array}{l}15 \% \\
(33) \\
\end{array}$ \\
\hline 9 & $\begin{array}{l}\text { Provide clear communication lines with } \\
\text { students, AET }\end{array}$ & 9 & $\begin{array}{c}9 \% \\
(18) \\
\end{array}$ & 9 & $\begin{array}{l}9 \% \\
(21) \\
\end{array}$ \\
\hline 10 & Follow/teach a curriculum & 8 & $\begin{array}{l}12 \% \\
(24)\end{array}$ & 12 & $\begin{array}{l}6 \% \\
(14)\end{array}$ \\
\hline
\end{tabular}

Note: Ranked $8^{\text {th }}$ among senior high AETs $\left(13^{\text {th }}\right.$ overall) was the role "Support/assist AET in class" (with 23 responses). 
childish or inappropriate behaviour from their older students. Moreover, fewer senior high teachers felt they should be supporters or counsellors for unsuccessful learners (2.6\% vs. $8.9 \%$ at junior high).

A comparison of Tables 3 and 4 reveals great disparity among AETs at the two school levels in their perceptions of JTE roles. Though calls for grammatical explanation and the teaching of grammar registered higher among junior high JTEs and AETs alike, it seems that a demand for whole translations prevailed at the higher grade levels. ${ }^{4}$ AETs saw "Translation" (which included 12 citings of "explanation") as the number one JTE role in senior high scholls, but only as the number four role in junior high schools. By contrast, Japanese teachers at both levels saw the roles of "Explainer, intermediator" and "Interpreter, interpretation if necessary" as almost equally important (at $33.4 \%$ and $34.5 \%$, and $7.0 \%$ and $7.6 \%$, respectively). An increasing need for English-Japanese translation, especially of higher-level English text, may be responsible for this juniorsenior split in AET opinion regarding JTE roles: as the level of English being studied increases (rather sharply, as some AETs noted), struggling students would have to rely more heavily upon their JTE for translations. Thus, there is a perception among AETs that the higher the level of English studied, the more a Japanese teacher may need to translate. In this sense, those who cannot keep up do not seem to be left behind.

Another curious discrepancy between Tables 3 and 4 involves the JTE's role in following or teaching a curriculum, which, although touched upon in other long-answer sections of the questionnaire, did not appear in JTE comments on roles. Again, the facts that 1) these questionnaires were administered in English and Japanese (with responses separately categorised and tallied by native speakers of each), and that 2) the responses under consideration were not confined to predesignated multiple-choice type categories, mean that the likelihood of exact correlations of data within, and particularly between, the two language groups, is bound to be extraordinarily low. Two reasons may explain the complete absence of Japanese remarks on following a curriculum. The Japanese word yakuwari, though listed in dictionaries under "role," more strongly conveys one's "part" or "share" in a mutual project than one's social duty. Another reason may be that, as AETs are invariably new to Japan's educational system and can at any time compare Japanese curricula to those of their home countries, they tend to have a heightened (or even exaggerated) perception of the limitations and pressures the school curriculum exerts. 
Whereas AETs may indeed feel intimidated by unfamiliar curricula, JTEs seem more apt to be concerned with problems related to individual students' levels and particular problems, or at least feel they should be. This seems particularly true among high school teachers surveyed, of whom $12 \%$ mention the importance for JTEs to understand their students' levels of achievement (connected, as it often is, with real-life circumstances). Though nearly $6 \%$ of junior high teachers (28 people) also described this type of role for JTEs, only a handful of AETs expressed the need for the main teacher to be able to "gauge students' levels" (2 respondents), "ensure activities are level-appropriate" (2), or "adopt ideas to students' abilities" (2), or simply to "know the students well" (6). These roles, important as they are to JTEs and the students, appear to pass largely unnoticed and therefore unappreciated by AETs: this in itself may produce stress for JTEs, as indicated for example in a JTE remark, "There is a problem with ALTs who do not understand students." A more significant number of AETs (10) did however report the need for JTEs to keep them (i.e. AETs) apprised of students' proficiency levels. This sentiment was echoed to some extent by 12 JTEs who felt they should "assist AETs with their lives in general at their affiliated schools" (7), "interpret Japanese culture for AETs" (3), or be "a morale supporter" (2) for their partner. All groups of team teachers implied that the JTE should know his or her students better than the AET knew them, and should make use of that insight. Future AET acknowledgement of such efforts, where they occur, would surely better team relations and benefit the JET Programme itself.

Finally, whereas JTE comments tended to ascribe the role of "motivator" to their native-speaking partners and that of student "supporter" to themselves, AETs saw the need for both teachers to motivate learners (while leaving individual "support" to their partners). Surely, the presence of a foreign and usually non-Japanese-speaking person in the classroom can, in and of itself, provide some motivation to communicate, at least in the short term. And the insider-knowledge to which JTEs have access does facilitate the role of supporting students. But support for unsuccessful learners may be offered by AETs too, particularly those with some Japanese ability and/or counselling skills. Moreover, motivation can certainly be offered by JTEs as well, whether by enticing students into English situational environments through activities, modelling English conversations with the AET in front of class, or by speaking English with their students directly. 
Some of this is of course already occurring. JTE attempts to motivate are visible, for example, in their role of being a "model, demonstrator of English conversation with AETs," which ranked tenth among junior high teachers and ninth among their senior high counterparts, and was echoed in AET comments on the JTE role of "model[ling] a communicative relationship" (Table 4, \#5). One may also acknowledge the JTE role of "encourag[ing] students," which ranked $10^{\text {th }}$, with 25 individual citations, among senior high JTEs. Finally, an AET role in supporting students was implied (though here, not thoroughly examined) in JTE remarks on "mood setting" and in the AET role of "develop[ing] friendship with students" (15 $5^{\text {th }}$ overall) since, as one senior high AET notes, some assistant teachers are perceived by students as "more than a friend but less than a teacher." Future inquiry into exactly how far JTEs and AETs can and do progress in what are usually regarded as each other's roles of motivating and supporting, respectively, would be of interest to JET Programme reformers and cultural theorists alike.

\section{Concluding Remarks}

This attempt to classify, outline, and explain over 1,400 teachers' perceptions of role responsibilities has proven challenging, and has perhaps brought forth more issues than it could ever aim to resolve. Still, it is important in an ever-changing programme as ambitious as JET, that large-scale questionnaires continue to be conducted and refined every few years, either with Ministry sponsorship or independently. In the future, some form of response from students who are being team-taught, if interpreted in conjunction with feedback from JTEs and AETs, would aid programme needs assessments and better inform efforts to improve team-taught classes for everyone concerned. Further articles that may be produced from the current data include comparisons of long-answer comments and multiple-choice responses on role-related questions, and further probing of respondents' general "concerns with team teaching" as revealed in long-answer format elsewhere in the questionnaire. It is hoped that JTEs and AETs will be able to make use of the role-related differences in opinion delineated in this paper in order to prepare for new team teachers or to discuss and perhaps even ameliorate current difficulties. Time strapped as many teachers find themselves, individualor programme-initiated opportunities for such communication among team teachers would not pass unrewarded. 


\section{Acknowledgements}

This article could not have been written without fellow researchers Shin-ichi Inoi, Takashi Yoshida, and Nobuya Itagaki, with whom the JET questionnaire was originally devised and conducted. Many thanks are owed for their enthusiastic support and invaluable advice.

Sean Mahoney, himself an AET in Fukushima Prefecture from 1995 to 97, is Assistant Professor of English at Fukushima University. His research interests include issues associated with teaching and learning English and multicultural education.

\section{Notes}

1. This paper is an elaboration of a presentation delivered by the author and Shin-ichi Inoi at JALT 2000 in Shizuoka.

2. The Ministry of Education restricts access to data on individual schools and teachers to officially sanctioned or sponsored research, a factor most likely responsible for the scarcity of extensive studies. Adachi et al. (1998), Yamada (Ed., 1996), and the present inquiry were all funded by the Ministry.

3. A number of Japanese teachers (121) made specific mention of the AET's role in teaching pronunciation and listening skills, as distinct from that of general language instruction, and did so often enough and apparently conscientiously enough to justify a separate role category for the Japanese data (see \#4 in Table 2, vis-à-vis \#2). This ran contrary to responses in English, in which work on pronunciation and listening were largely assumed (in all but eight cases) to accompany conversation. Nonetheless, even if one were to ignore this subtle but important JTE distinction and combine the response frequencies of JTE categories 2 and 4 in Table 2, an act which would bring Japanese perspectives on the number one AET role to an almost even split between that of a language model and a cultural model (up to $35.6 \%$ of total JTE responses, just behind $37.0 \%$ ), the JTE data would still stand in contrast to that obtained from AETs (50.5\% vs. 41.1\%).

4. A note here on the concepts of translation vs. interpretation, the latter of which was hardly mentioned in AET (i.e. English) comments: while the Japanese word honyaku can refer to either written (more 
common) or oral translation, tsuuyaku refers to oral translation only. Japanese speakers, especially language professionals, make clearer distinctions between the two activities, and thus two separate categories have been preserved here.

\section{References}

Adachi, K., Macarthur, J., \& Sheen, R. (1998). Perceptions of the JET programme. Osaka: Keisuisha.

Brumby, S., \& Wada, M. (1990). Team teaching. Essex: Longman Group UK Ltd. Council of Local Authorities for International Relations. (2001). JET Puroguramu hyouka chosa [An evaluative examination of the JET Programme]. Tokyo: Author (CLAIR).

Crooks, A. (2001). Professional development and the JET Program: Insights and solutions based on the Sendai City program. JALT Journal, 23(1), 31-46.

Garant, M. (1992) Traditional, semi-traditional, and nontraditional team teaching in Japanese junior high schools. The Language Teacher, 16(11), 25-29.

Inoi, S., Yoshida, T., Mahoney, S., \& Itagaki, N. (2001). An inquiry into JTE and ALT/AET beliefs about English education. Tokyo: Monbukagakusho.

Institute for Research in Language Teaching. (1988). Chugakkou, koutougakkou eigoka kyouiku ni okeru gaikokujinkyoushi no yakuwari ni kansuru jittaichousa to jugyouhouhou no kaiten [Survey on the roles of foreign teachers of English at junior and senior high schools: classroom methodology and development]. The IRLT Bulletin, 2, 1-108. Tokyo: Author.

JET Programme 2003. (2003, 1 July). 2003-2004 Participant Totals by Country. Retrieved on 19 September 2003, from http://www.jetprogramme.org/e/ outline/data/ Page1. html

Johnson, K. E. (1992). The relationship between teachers' beliefs and practices during literacy instruction for nonnative speakers of English. Journal of Reading Behavior, 24(1), 83-108.

Kahny, J., Olivieri, D., \& Maybin, D. (1992). Six aspects of a successful team teaching program. The Language Teacher 16(11), 41-45.

Lai, M. L. (1999). Jet and Net: A comparison of native-speaking English teachers schemes in Japan and Hong Kong. Language Culture and Curriculum 12(3), 215-228.

Leonard, T. J. (1994). Team teaching together. Tokyo: Taishukan.

Lynch, T. (1989). Researching teachers: Behaviour and belief. In C. Brumfit \& R. Mitchel (Eds.), Research in the Language Classroom. Modern English Publications in association with The British Council.

McConnell, D. L. (2000). Importing Diversity: Inside Japan's JET Program. Berkeley: University of California Press.

Monbusho (1994). Handbook for team teaching. Tokyo: Author. 
Monbusho (1989). Kotogakkou gakushushido Ryoryo [Course of Study for Senior High Schools]. Tokyo: Author.

Pattimore, R., \& Kobayashi, K. (1999, October). JTE attitudes towards team teaching. Paper presented at JALT 1999, Maebashi, Japan.

Sturman, P. (1992). Team teaching: A case study from Japan. In D. Nunan (Ed.), Collaborative language learning and teaching (pp. 141-161). Cambridge: Cambridge University Press.

Voci-Reed, E. (1994). Stress factors in the team teaching relationship. In M. Wada and A. Cominos (Eds.), Studies in team teaching (pp.61-71). Tokyo: Kenkyusha.

Wada, M., \& Cominos, A. (1994). Studies in team teaching. Tokyo: Kenkyusha.

Woods, D. (1991). Teachers' interpretations of second language teaching curriculum. RELC Journal, 22(2), 1-18.

Yamada, K. (Ed.). (1996). Chuu, koutougakkou ni okeru JET Puroguramu no genjou to kadai [Current issues concerning the JET Programme in junior and senior high schools]. Tokyo: Monbusho.

Yukawa, E. (1992). Team teaching and changes in teaching routines. The Language Teacher, 16(11), 9-13.

(Received December 31, 2003; accepted May 8, 2004) 